\title{
Towards the Application of Atorvastatin to Intensify Proapoptotic Potential of Conventional Antileukemic Agents In Vitro
}

\author{
Jolanta D. Żołnierczyk, ${ }^{1}$ Arleta Kaźmierczuk, ${ }^{1}$ Paweł Hikisz, ${ }^{1}$ \\ Barbara Cebula-Obrzut, ${ }^{2}$ Ewa Wawrzyniak, ${ }^{3}$ Jerzy Z. Błoński, ${ }^{3}$ Małgorzata Misiewicz, \\ Pawel Robak, ${ }^{2}$ Piotr Smolewski, ${ }^{2}$ and Zofia M. Kiliańska ${ }^{1}$ \\ ${ }^{1}$ Department of Cytobiochemistry, Faculty of Biology and Environmental Protection, University of Łódź, 90-236 Łódź, Poland \\ ${ }^{2}$ Department of Experimental Hematology, Medical University of Łódź, 93-510 Łódź, Poland \\ ${ }^{3}$ Department of Hematology, Medical University of Łódź, 93-510 Łódź, Poland \\ Correspondence should be addressed to Zofia M. Kiliańska; zkilian@biol.uni.lodz.pl
}

Received 4 December 2014; Revised 5 March 2015; Accepted 5 March 2015

Academic Editor: Philippe Jeandet

Copyright (C) 2015 Jolanta D. Żołnierczyk et al. This is an open access article distributed under the Creative Commons Attribution License, which permits unrestricted use, distribution, and reproduction in any medium, provided the original work is properly cited.

\begin{abstract}
It has been previously revealed that statins used at high concentrations display antileukemic potential towards chronic lymphocytic leukemia (CLL) cells. However, their usage alone in clinical practice may be limited due to possible side effects of high doses of these drugs. On the other hand, combined treatment of leukemia with statins and the conventional chemotherapeutics is questionable because of unknown influence of the first on the standard treatment results. This study has revealed that in vitro atorvastatin increases the proapoptotic potential of cladribine and mafosfamide in CLL cells isolated from peripheral blood of patients. Moreover, a preincubation with the above statin sensitizes leukemic cells to CM-induced apoptosis even at small concentrations of the drug. The usage of atorvastatin together with or followed by the conventional chemotherapy should be considered as therapeutic option for the treatment for this leukemia. Interestingly, CM-resistant patients might have the biggest benefits from atorvastatin administration.
\end{abstract}

\section{Introduction}

Despite a large number of therapeutic options introduced recently, chronic lymphocytic leukemia (CLL) remains still an incurable disease. An increase in lymphocyte level is caused by decreased apoptosis process and elevated survival due to both intrinsic properties of leukemic cells and microenvironmental stimuli. The disease is highly heterogeneous with variable clinical course and prognosis [1]. The new strategies for CLL treatment are still being developed [2-4]. Currently, much attention is focused on monoclonal antibodies, that is, rituximab and alemtuzumab, which target CD20 and CD52 antigens, respectively. Rituximab, cyclophosphamide, and fludarabine combination (RCF) is thought to be the gold standard in CLL treatment [5]. However, some patients are excluded from immunotherapy since RCF regimen augments the risk of myelosuppression [2]. Known anaphylaxis or hypersensitivity to murine proteins is counterindications to monoclonal antibodies usage. Furthermore, rituximab administration increases significantly a risk of development of severe infections [6]. Therefore, very high carefulness is needed in the treatment of CLL patients with opportunistic, recurrent, or chronic infections. In addition, hypersensitivity pneumonitis is rare, but life-threatening adverse effect of the antibody injection that is an indication to rituximab discontinuation [7]. Simultaneously with the progress in immunotherapy, improvement in conventional chemotherapy efficiency should also take place. 
Numerous defects have been revealed in lipid metabolism of CLL cells. Contrary to the normal B lymphocytes, the leukemic cells exhibit overexpression of lipoprotein lipase (LPL), the enzyme which facilitates the hydrolysis of serum lipoprotein triacylglycerols(triglycerides) to free fatty acids (FFA) [8]. LPL generates ligands for peroxisome proliferator activated receptor $\alpha(\operatorname{PPAR} \alpha)$ involved in fatty acid $\beta$ oxidation [9]. The elevated level of this nuclear receptor has been indicated within the quiescent CLL cells and it has been correlated with advancement of the leukemia. The elevated concentrations of LPL as well as PPAR $\alpha$ in the lymphocytes change their metabolism towards higher utilization of FFA $[8,9]$. Moreover, it seems that in addition to its lipolytic activity LPL must serve an extra vital function in the cells, deregulation of which may be related to aggressive course of the leukemia [8].

Mulas et al. [10] have demonstrated that both CLL and ALL (acute lymphocytic leukemia) patients are characterized by decreased serum level of high density lipoproteins (HDL), as well as increased level of cholesterol esters within the leukemic lymphocytes in comparison to normal ones. Moreover, the cited scientists observed the elevated level of cholesterol esterification in the cells that had been treated with mitogens, while its decreasing level when the neoplastic lymphocytes had been exposed to inhibitor of cel proliferation such as the mTOR inhibitor, RAD. They have suggested that cholesterol esterification might be a mode for cellular growth control which goes via the regulation of free cholesterol concentration in lipid rafts. Hence, the statins, drugs affecting cholesterol biosynthesis by 3-hydroxy-3-methyl-glutharylcoenzyme A (HMG-CoA) reductase inhibition, could be promising compounds targeting cholesterol-dependent pathways of leukemic cells' growth and proliferation.

Although not fully understood, anticancer activity of statins has been well documented [11-13]. It is thought to be associated mainly with inhibition of mevalonate (MVA) pathway that is a source of molecules being of great importance for cellular survival, that is, ubiquinone, dolichol, farnesyl pyrophosphate (FPP), geranylgeranyl pyrophosphate (GPP), and so forth [14-17]. These compounds determine proper course of cellular respiration, glycoprotein assembling, or prenylation of proteins engaged in intracellular signalization (Rho, Ras, Rab, and Rac), respectively $[18,19]$. Moreover, it was reported that statins downregulate histone methyltransferase enhancer of zeste homolog 2 (EZH2) in colorectal cancer cells, leading to p27 $7^{\mathrm{KIP} 1}$ overexpression, cell cycle arrest, and inhibition of tumor progression [20].

It has been previously revealed that statins indicate cytotoxic potential also against CLL cells in vitro $[21,22]$. Leukemic lymphocytes seem to indicate particularly high demand for intermediate products of cholesterol biosynthesis or cholesterol alone, which makes them more susceptible to the blockage of HMG-CoA reductase activity than normal ones [22].

The purpose of the current research was to compare the proapoptotic activity of synthetic compound, atorvastatin, with CM (cladribine + mafosfamide/cyclophosphamide) drug combination which is conventionally used for CLL treatment. Moreover, we aimed to establish atorvastatin influence on the antileukemic activity of CM against primary tumor peripheral blood mononuclear cells (PBMCs) in vitro.

\section{Experimental}

2.1. Patients. PBMCs were obtained from blood of 24 untreated CLL patients (18 men, 6 women) prior to the introduction of the anticancer therapy. The patients' characteristics are given in Table 1.

CLL was diagnosed on the basis of standard clinical and immunological criteria and the clinical stage. The disease was classified according to modified Rai system [23]. Leukemic PBMCs were characterized by the expression of CD5, CD19, and CD23 antigens on the surface and monoclonality for light chains of their immunoglobulins. This study was approved by the Local Ethics Committee of Medical University of Łódź (number $\mathrm{RNN} / 143 / 10 / \mathrm{KE}$ ) and all the patients gave their written consent.

2.2. Isolation of Mononuclear Cells. PBMCs were isolated from freshly obtained peripheral blood samples (collected into EDTA) by Histopaque-1077 density gradient centrifugation (Sigma-Aldrich, St. Louis, MO, USA).

2.3. Fluorescence In Situ Hybridization (FISH). FISH was performed on interphase nuclei of PBMCs obtained from untreated CLL patients as previously described. The following commercially available probes were used: LSI D13S319 (13q14.3)/LSI 13q34/CEP 12 probe, LSI p53 (17p13.1)/LSI ATM (11q22.3) probe (Vysis/Abbott Molecular, USA). For each probe, 200 interphase nuclei were scored. The estimated cutoff levels were as follows: $8 \%$ for $\operatorname{del}(13)(q 14.3), \operatorname{del}(11)(q 22.3)$, $\operatorname{del}(17)(\mathrm{p} 13.1)$, and 5\% for trisomy, respectively.

2.4. Cytometric Analysis of ZAP70 Expression. In several cases, the assays of the intracellular expression of zeta chain- (TCR-) associated protein kinase 70 (ZAP70) in $\mathrm{CD}^{+} / \mathrm{CD} 19^{+}$leukemic cells from previously untreated CLL patients were made. The detection of ZAP70 was performed according to the permeabilization and staining procedure of Invitrogen Molecular probes. Briefly, $50 \mu \mathrm{L}$ of peripheral blood samples was incubated with FITC-conjugated antiCD5 and PerCP-conjugated anti-CD19 antibodies (or the appropriate isotype controls) from Becton Dickinson for $15 \mathrm{~min}$ in the dark at room temperature. Afterwards, $100 \mu \mathrm{L}$ of fixation medium from Invitrogen Molecular Probes was added to the each sample. After $15 \mathrm{~min}$ incubation the samples were washed in $3 \mathrm{~mL}$ PBS $+0.1 \% \mathrm{NaN}_{3}+5 \% \mathrm{FBS}$ and centrifuged for $5 \mathrm{~min}$ at $300 \times \mathrm{g}$. Then, the supernatant was aspirated and $100 \mu \mathrm{L}$ of Permeabilization Medium from Invitrogen Molecular Probes and PE-conjugated anti-ZAP70 antibody (or the corresponding isotype control) from BioLegend (San Diego, CA, USA) were added. After incubation (20 min), blood cell samples were washed again in $3 \mathrm{~mL}$ PBS $+0.1 \% \mathrm{NaN}_{3}+5 \%$ FBS and centrifugated for $5 \mathrm{~min}$ at $300 \times \mathrm{g}$. Then, supernatant was removed, whereas the cells were resuspended in sheath fluid and immediately analyzed 
TABLE 1: Characteristic of CLL patients.

\begin{tabular}{|c|c|c|c|c|c|c|c|c|}
\hline \multirow{2}{*}{$\begin{array}{rr} & \text { Sex } \\
1 & M\end{array}$} & \multirow{2}{*}{$\begin{array}{l}\text { Age } \\
80\end{array}$} & \multirow{2}{*}{$\begin{array}{c}\begin{array}{c}\text { Stage } \\
\text { of CLL }\end{array} \\
\text { II }\end{array}$} & \multirow{2}{*}{$\begin{array}{l}\text { Leukocytosis } \\
{\left[\times 10^{9} / \mathrm{L}\right]}\end{array}$} & \multirow{2}{*}{$\begin{array}{l}\text { Chromosomal } \\
\text { abnormalities [analyzed } \\
\text { by FISH technique] }\end{array}$} & \multirow{2}{*}{$\begin{array}{l}\text { Sensitivity of PBMC to } \\
\text { CM [\% of dead cells in } \\
\text { comparison to control] }\end{array}$} & \multicolumn{3}{|c|}{$\begin{array}{c}\text { Sensitivity of PBMC to } 10 \mu \mathrm{M}, 25 \mu \mathrm{M} \text {, and } 50 \mu \mathrm{M} \\
\text { atorvastatin, respectively [\% of dead cells in } \\
\text { comparison to control] }\end{array}$} \\
\hline & & & & & & $14.1 \%$ & $17.5 \%$ & $29.9 \%$ \\
\hline $2 \mathrm{M}$ & 51 & I & 46 & del 11q22 & $54 \% \mathrm{~S}$ & $12.7 \%$ & $26.7 \%$ & $51.9 \%$ \\
\hline $3 \mathrm{M}$ & 68 & I & 300 & del 13q14 & $78.2 \% \mathrm{~S}$ & $19.2 \%$ & $29.7 \%$ & $47.1 \%$ \\
\hline $4 \mathrm{M}$ & 77 & IV & 300 & del 11q22, del 13q14 & $3.7 \% \mathrm{R}$ & $4.7 \%$ & $15.2 \%$ & $30.3 \%$ \\
\hline $5 \mathrm{M}$ & 53 & I & 64 & $\mathrm{~N}$ & $67.4 \% \mathrm{~S}$ & $15.4 \%$ & $27.2 \%$ & $46.8 \%$ \\
\hline $6 \mathrm{~F}$ & 60 & IV & 300 & ND & $64.8 \% \mathrm{~S}$ & $20.3 \%$ & $35.1 \%$ & $32.8 \%$ \\
\hline $7 \mathrm{M}$ & 56 & III & 224 & ND & $60.4 \% \mathrm{~S}$ & $22.1 \%$ & $25.3 \%$ & $35.4 \%$ \\
\hline $8 \mathrm{M}$ & 75 & III & 200 & $\mathrm{~N}$ & $41.8 \% \mathrm{~S}$ & $20.2 \%$ & $27.8 \%$ & $40.3 \%$ \\
\hline $9 \mathrm{M}$ & 69 & IV & 300 & del 13q14 & $10.4 \% \mathrm{R}$ & $16.6 \%$ & $25.4 \%$ & $41.6 \%$ \\
\hline $10 \mathrm{M}$ & 65 & II & 260 & del 13q14 & $77.4 \% \mathrm{~S}$ & $20.7 \%$ & $28 \%$ & $42 \%$ \\
\hline $11 \mathrm{~F}$ & 72 & III & 129 & del 17p13 & $14.7 \% \mathrm{R}$ & $9.8 \%$ & $16.8 \%$ & $27.8 \%$ \\
\hline $12 \mathrm{M}$ & 56 & IV & 136 & del 13q14 & $64.5 \% \mathrm{~S}$ & $19.5 \%$ & $29.3 \%$ & $49.2 \%$ \\
\hline $13 \mathrm{M}$ & 72 & II & 220 & ND & $50 \% \mathrm{~S}$ & $29.7 \%$ & $48.8 \%$ & $71.55 \%$ \\
\hline $14 \mathrm{M}$ & 68 & III & 170 & del 13q14 & $45.1 \% \mathrm{~S}$ & $31 \%$ & $43.9 \%$ & $55.2 \%$ \\
\hline $15 \mathrm{M}$ & 59 & IV & 190 & del 13q14 & $10.8 \% \mathrm{R}$ & $12 \%$ & $27.1 \%$ & $45.2 \%$ \\
\hline $16 \mathrm{~F}$ & 65 & II & 180 & $\mathrm{~N}$ & $30.2 \% \mathrm{~S}$ & $20.7 \%$ & $25 \%$ & $28.5 \%$ \\
\hline $17 \mathrm{~F}$ & 63 & IV & 150 & del 13q14 & $2.7 \% \mathrm{R}$ & $26.2 \%$ & $38.8 \%$ & $46.6 \%$ \\
\hline $18 \mathrm{~F}$ & 56 & IV & 350 & $\mathrm{~N}$ & $4.4 \% \mathrm{R}$ & $34.7 \%$ & $51.9 \%$ & $75.3 \%$ \\
\hline $19 \mathrm{M}$ & 66 & IV & 600 & del 13q14, del 11q22, +12 & $18.7 \% \mathrm{P}$ & $12.1 \%$ & $27.1 \%$ & $49.4 \%$ \\
\hline $20 \mathrm{M}$ & 61 & I & 150 & +12 & $2.4 \% \mathrm{R}$ & $1.6 \%$ & $8.8 \%$ & $13 \%$ \\
\hline $21 \mathrm{~F}$ & 81 & I & 28 & ND & $26.3 \% \mathrm{P}$ & $7.9 \%$ & $22.9 \%$ & $29.9 \%$ \\
\hline $22 \mathrm{M}$ & 80 & III & 30 & ND & $42.3 \% \mathrm{~S}$ & $5.7 \%$ & $7.5 \%$ & $21.1 \%$ \\
\hline $23 \mathrm{M}$ & 59 & 0 & 80 & del 11q22 & $16 \% \mathrm{P}$ & $10.5 \%$ & $1.6 \%$ & $10.8 \%$ \\
\hline $24 \mathrm{M}$ & 71 & I & 77 & ND & $18.6 \% \mathrm{P}$ & $11.1 \%$ & $14.4 \%$ & $21.8 \%$ \\
\hline
\end{tabular}

*Atypical CLL with only 15\% of CD5+/CD19+ cells, N: normal karyotype, ND: not determined, +12: trisomy 12, del: deletion, F: female, M: male, P: PBMCs partially sensitive to cladribine + mafosfamide drug combination, S: PBMCs sensitive to cladribine + mafosfamide, and R: PBMCs resistant to cladribine + mafosfamide.

with FACS Canto II (Becton-Dickinson, San Jose, CA, USA) flow cytometer.

2.5. Cell Culture and Drug Treatment. After washing of PBMCs with phosphate-buffered saline (PBS), the cell samples $\left(2 \times 10^{6} / \mathrm{mL}\right)$ were resuspended in RPMI 1640 medium with $10 \%$ fetal calf serum supplemented with $2 \mathrm{mM} \mathrm{L-}$ glutamine, $100 \mu \mathrm{g} / \mathrm{mL}$ streptomycin, and $100 \mathrm{U} / \mathrm{mL}$ penicillin. PBMCs were incubated for 24 and $48 \mathrm{~h}$ in standard conditions, that is, at $37^{\circ} \mathrm{C}$ in an atmosphere of $5 \% \mathrm{CO}_{2}$. The model cells were exposed to atorvastatin at $10 \mu \mathrm{M}$, $25 \mu \mathrm{M}$, and $50 \mu \mathrm{M}$, combinations of cladribine and mafosfamide (an active form of cyclophosphamide), as well as cladribine, mafosfamide, and atorvastatin. The cell samples without drug(s) or with DMSO (solvent for atorvastatin) were considered as controls (Ctr) and vehicle controls, respectively. Cladribine and mafosfamide were added to culture medium at concentrations which corresponded to their concentrations in serum of CLL patients during CC (cladribine + cyclophosphamide) chemotherapy: $0.175 \mu \mathrm{M}$ and $2.5 \mu \mathrm{M}$, respectively.
Atorvastatin was purchased from LKT Laboratories Inc. Cladribine was obtained from the Institute of Biotechnology and Antibiotics, Bioton (Warsaw, Poland), whereas mafosfamide was from Baxter Oncology GmbH (Frankfurt, Germany).

Moreover, to evaluate whether a pretreatment of CLL cell probes with smaller doses of atorvastatin has an impact on the cell susceptibility to conventional chemotherapeutic agents, that is, cladribine and mafosfamide, PBMCs were incubated with $0.1 \mu \mathrm{M}$ and $1 \mu \mathrm{M}$ of atorvastatin for $24 \mathrm{~h}$. Then, the culture medium was changed and the cells were exposed to $\mathrm{CM}$ for next $48 \mathrm{~h}$.

2.6. Cell Viability and Apoptosis/Necrosis Rate. To evaluate the viability of leukemic PBMCs, as well as the percent of apoptotic and necrotic cells in the populations of PBMCs exposed to the tested agents Membrane Permeability/Dead Cell Apoptosis Kit from Invitrogen Molecular Probes (Eugene, OR) was used according to the manufacturer's protocol. The mononuclear cell population was gated on the basis of FSC (forward scatter) and SSC (side scatter) 
parameters. The analyses were made after 24 and $48 \mathrm{~h}$ cell exposure to the investigated drugs and quantified using LSR II cytometer (Becton-Dickinson, San Jose, CA, USA).

In 4 experiments cell viability and apoptosis rate were evaluated after the preincubation with atorvastatin, as well as after 24 and $48 \mathrm{~h}$ exposure to CM. The results were compared with those obtained for a coincubation of PBMCs from the same patients with atorvastatin in combination with CM for $48 \mathrm{~h}$.

2.7. Caspase-3 Activation. To assess the percent of PBMCs with active form of caspase- 3 in control and drug-treated cell population PE active caspase-3 apoptosis kit (BD Pharmingen, San Diego, CA) was used. The analyses were performed after $48 \mathrm{~h}$ of incubation with the tested agents according to manufacturer's protocol. The measurements were made by LSR II flow cytometer (Becton-Dickinson, San Jose, CA, USA).

2.8. DNA Content. DNA content in PBMC samples was estimated after 24 and $48 \mathrm{~h}$ incubation with/without tested drugs as it was previously described [22]. Briefly, $1 \times 10^{6}$ cells were fixed with $70 \%$ ethanol and incubated at $-20^{\circ} \mathrm{C}$ for $2 \mathrm{~h}$. Subsequently, the cells were incubated in the presence of RNAse A (at final concentration in PBS of $0.5 \mathrm{mg} / \mathrm{mL}$ ) and propidium iodide (PI; at final concentration in PBS of $0.01 \mathrm{mg} / \mathrm{mL}$ ) for $30 \mathrm{~min}$, at $37^{\circ} \mathrm{C}$ in the dark. Then, the fluorescence of PI was measured by flow cytometry (FACS Canto II; Becton-Dickinson, San Jose, CA, USA) and the number of sub-G1 cells was estimated on the basis of FL3 histograms using FACS Diva Software (Becton-Dickinson, San Jose, CA, USA). Ten thousand events were examined for each analysis.

2.9. Protein Separation and Immunoblotting. Leukemic PBMCs were lysed and prepared for Western blot analysis as it was previously described [24]. A protein quantitation in the cell lysates was performed according to Lowry method [25]. About $50 \mu \mathrm{g}$ of proteins was loaded per each lane and the probes were separated by SDS-PAGE into $8 \%$ and $12.5 \%$ slab gels, depending on the molecular weights of the analyzed proteins, respectively [26]. Then, the proteins were transferred onto immobilon $\mathrm{P}$ according to Towbin et al. [27] and stained reversibly with $0.05 \%$ Ponceau S solution to confirm their equal loading. Subsequently, the membranes were incubated in the presence of $5 \%$ nonfat dry milk in TBST buffer $(10 \mathrm{mM}$ Tris- $\mathrm{HCl}(\mathrm{pH}$ 7.5), $150 \mathrm{mM} \mathrm{NaCl}$, and $0.05 \%$ Tween 20) for $1 \mathrm{~h}$ at room temperature with successive incubation overnight with specific antibodies in the following dilutions: anti-PARP-1 (1:5000; sc-7150), anti-lamin B (1:2000; sc-6216), anticaspase-9 (1:5000; sc-8355), anti-Mcl-1 (1:5000; sc-819), anti-Bcl-2 (1:1000; sc-492), and anti-Bax (1:1000; sc1035), all from Santa Cruz Biotechnology (Santa Cruz, CA), anti-caspase-3 (1:1000) from Sigma-Aldrich, antiZAP70 (1:1000) from Cell Signaling, as well as anti-actin (1:1000) antibody from Abcam (Cambridge, UK). After being washed 3 times in TBST buffer, the membranes were incubated with secondary antiserum conjugated with alkaline phosphatase (Sigma-Aldrich) for $2 \mathrm{~h}$ and washed 3 times again. The antigen-antibody complexes were visualized after incubation of membranes with a phosphatase substrate solution containing: $0.33 \mathrm{mg} / \mathrm{mL}$ of nitro blue tetrazolium, $0.17 \mathrm{mg} / \mathrm{mL}$ of 5-bromo-4-chloro-3-indolyl phosphate in $100 \mathrm{mM}$ Tris- $\mathrm{HCl}$ (pH 9.5), $100 \mathrm{mM} \mathrm{NaCl}$, and $5 \mathrm{mM} \mathrm{MgCl}$. In some experiments, secondary antibodies conjugated with horse radish peroxidase were applied. Then, Novex HRP chromogenic substrate (TMB) from Invitrogen was applied for detection of proteins.

2.10. Statistical Analysis. All results are presented as the mean value \pm S.D. The statistical data analysis was performed by Anova with Tukey's post hoc test. The data obtained for atorvastatin and the combinations of atorvastatin with CM were compared with the results from DMSO treated cells (vehicle control), whereas CM combination effectiveness was compared with the model cells incubated without drugs (Ctr). The results were considered statistically significant at $p \leq 0.05$.

Moreover, the Wilcoxon signed rank test was used to statistically evaluate the differences in cytotoxicity of the tested drugs in CM-sensitive and CM-resistant groups of PBMC samples.

\section{Results and Discussion}

3.1. FISH Analysis. In the current study, 4 of 18 analyzed CLL patients indicated normal FISH results (see Table 1). The most common chromosomal abnormality detected among the examined group of CLL patients was deletion of 13q14 (8 patients), which is generally observed in $\sim 70 \%$ of patients with CLL and is associated with good prognosis as a sole abnormality [2]. Deletions of 17p13 and 11q22-q23 were found in 1 and 2 CLL patients enrolled in FISH analysis, respectively. These chromosomal aberrations are both connected with loss of function of TP53 tumor suppressor gene as well as the resistance to purine analogs and are related to worst (ATM) and the worst (TP53) prognosis $[1,4,5]$. Two CLL patients were characterized by deletions of 11q22 together with $13 q 14$ and deletion of 11q22 associated with del 13q14 and trisomy 12, respectively. Trisomy 12 as a sole abnormality was observed in one patient only.

In the current study the proapoptotic potential of atorvastatin alone, as well as in combination with $\mathrm{CM}$, was not related to the presence of high risk prognostic markers, such as del 17p13 or del 11q22-23.

3.2. Cell Viability and Apoptosis/Necrosis Evaluation. To verify whether the drugs frequently prescribed for elder people in connection with the hypercholesterolemia could be profitable or inversely unfavourable for the cured CLL patients who are usually over 60 years old we tested both higher and lower concentrations of atorvastatin with regard to its putative proapoptotic potential against CLL cells.

The viability of PBMCs obtained from blood of $24 \mathrm{CLL}$ patients enrolled in the study was essentially decreased by 


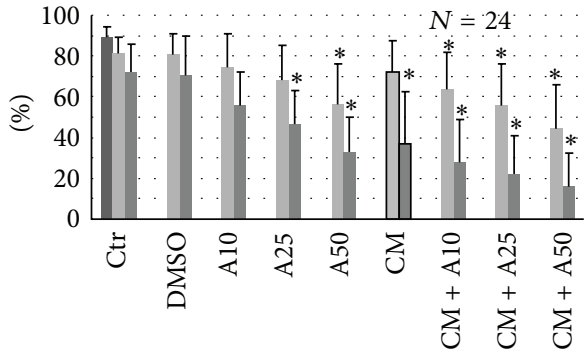

- $0 \mathrm{~h}$

- $24 \mathrm{~h}$

- $48 \mathrm{~h}$

(a) Cell viability by Membrane Permeable/Dead Cell Apoptosis Kit
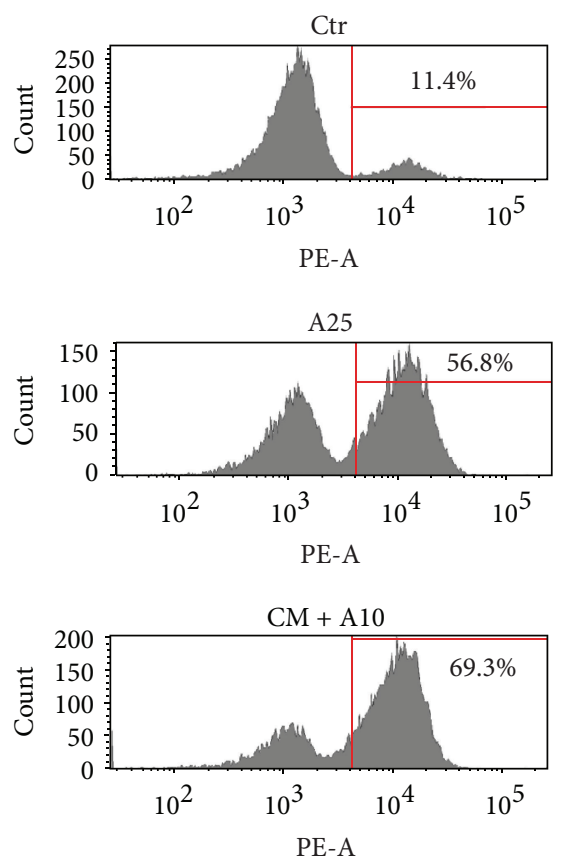

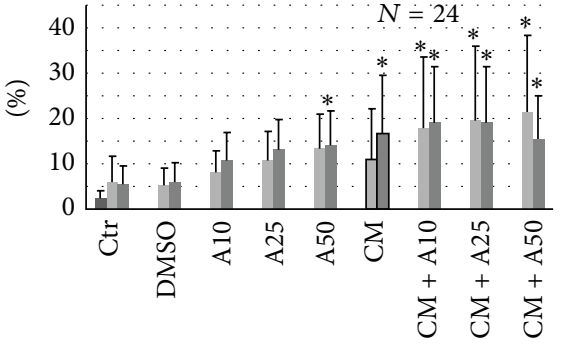

- $0 \mathrm{~h}$

- $24 \mathrm{~h}$

- $48 \mathrm{~h}$

(b) Apoptosis induction by Membrane Permeable/Dead Cell Apoptosis Kit
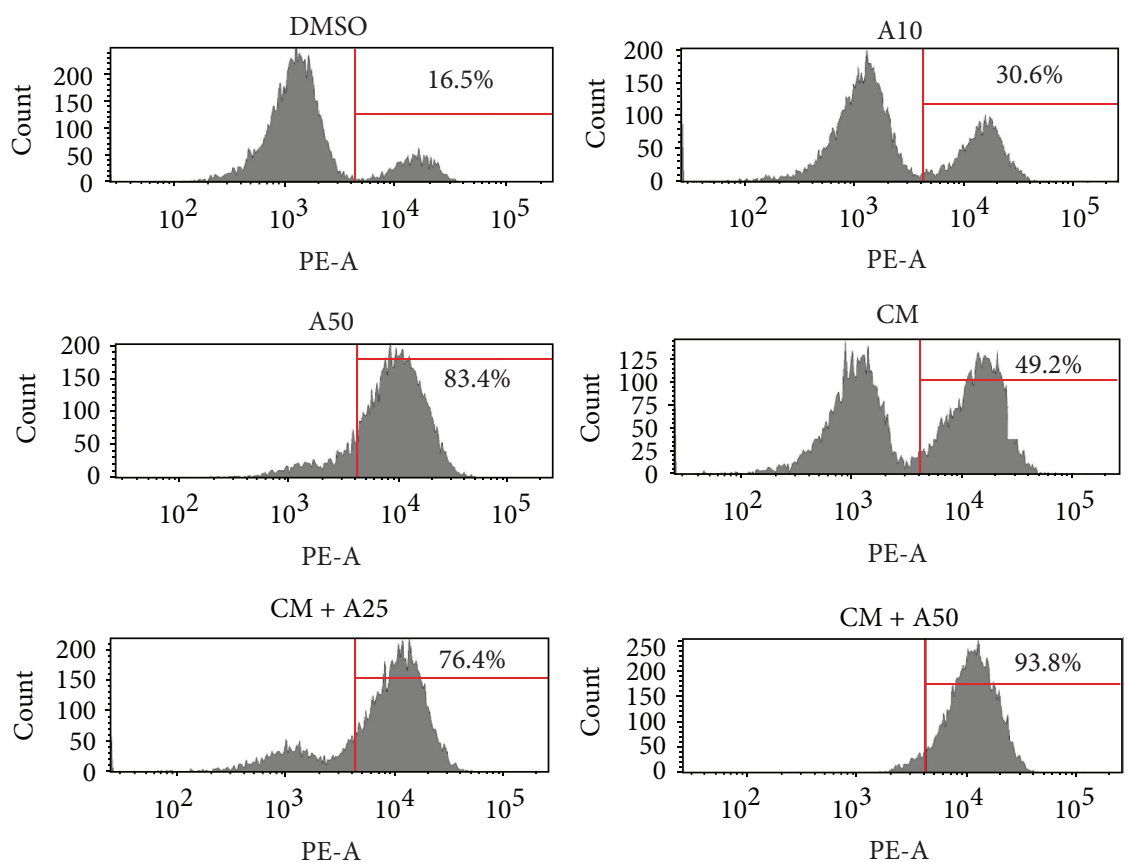

(d) Apoptosis induction on the basis of caspase-3 activation in PBMCs from exemplary patient number 13

FIGURE 1: Antileukemic potential of atorvastatin (A), cladribine + mafosfamide combination (CM), or atorvastatin in combination with cladribine + mafosfamide $(\mathrm{CM}+\mathrm{A})$ evaluated on the basis of cell viability (a) and apoptosis induction (b-d) examination after 24 and $48 \mathrm{~h}$ CLL cell exposure. Proapoptotic activity of the tested drugs was evaluated by Permeable/Dead Cell Apoptosis Kit (b), DNA content analysis (c), and PE active caspase- 3 apoptosis kit (d). ${ }^{*}$ the results were statistically significant at $p \leq 0.05$.

atorvastatin used alone (A), as well as atorvastatin in combination with cladribine and mafosfamide (CM), that is, $\mathrm{CM}+$ A. The assays of early apoptotic cell number in population of the examined probes exposed to the used agents confirmed proapoptotic potential of atorvastatin, as well as the conventional applied combination, CM. The average cytotoxicity and proapoptotic activity of the tested drugs are presented in Figures 1(a) and 1(b). A combination of purine analog and the alkylator exhibits strong proapoptotic potential, especially after $48 \mathrm{~h}$. Cell exposure to CM $24 \mathrm{~h}$ was less efficient than $24 \mathrm{~h}$ exposure to $25 \mu \mathrm{M}$ and $50 \mu \mathrm{M}$ atorvastatin. After $48 \mathrm{~h}$, however, the impact of $25 \mu \mathrm{M}$ compound was comparable to the action of CM combination. Although there was not established maximal dose of statin that could be used in human without inducing potent cytotoxicity, this drug concentration might be unattainable for anticancer therapy. Therefore, we evaluated the potential of $\mathrm{CM}+\mathrm{A}$ combination to induce apoptosis in CLL cells. A combined treatment of $\mathrm{CM}$ and $10 \mu \mathrm{M}$ atorvastatin (CMA10) was more effective than CM. The improvement in antileukemic potential of tested drugs in comparison to CM alone was about $10 \%$ as assessed by Membrane Permeability/Dead Cell Apoptosis kit. The $48 \mathrm{~h}$ incubation of the model cell samples with CM used in combination with $50 \mu \mathrm{M}$ atorvastatin was associated with widespread late apoptosis/secondary necrosis of PBMCs (Figure 1). 
The cell samples were divided on the basis of their sensitivity towards the conventional chemotherapeutic combinations in vitro. We classified them into one of three groups (compare Table 1): the first one: CM-sensitive (S), the second one: partially sensitive $(\mathrm{P})$, and the third one: CM-resistant (R), when CLL cell exposure to CM decreased cell viability over $30 \%, 15 \%-30 \%$, and less than $15 \%$ after $48 \mathrm{~h}$, respectively. As it is illustrated in Table 1 among examined 24 CLL cell samples the biggest group $(13 ; 54 \%)$ responded to CM, but 7 cases $(29 \%)$ did very weakly. Four cases (17\%) indicated partial response to $\mathrm{CM}$.

When we compared the average cytotoxicity of atorvastatin, CM, and their combination in CM-resistant PBMCs in vitro the used statin, even at the lowest concentration, caused higher antileukemic potential than CM drug combination (shown in Figure 2-R). In all of leukemic cell samples which were classified as CM resistant, $25 \mu \mathrm{M}$ atorvastatin decreased the cell viability with higher efficiency than CM. Moreover, a combination of atorvastatin and CM caused potentiated cytotoxic effect in leukemic PBMCs in comparison to CM. In 6 of $7 \mathrm{CM}$-resistant cell samples atorvastatin at $10 \mu \mathrm{M}$ triggered apoptosis of PBMCs at higher degree than the $\mathrm{CM}$ after $48 \mathrm{~h}$. Differences in the cytotoxicity induced by $\mathrm{CM}+$ $\mathrm{A} 25$ and $\mathrm{CM}+\mathrm{A} 50$ versus $\mathrm{CM}$ were statistically significant at $p<0.05$ and $p<0.02$, respectively (Wilcoxon signed rank test). The average decrease in the viability of CMA10-treated cells was $\sim 20 \%$ in comparison to the cell samples exposed to CM.

From among all the tested cell samples, only the examined probes obtained from blood of the patient number 20 were not susceptible to both $\mathrm{CM}$ and atorvastatin. In the rest of investigated CLL samples the resistance to conventional anticancer drug combination - CM did not go together with their resistance towards atorvastatin which is related to their different mechanisms of action against the model cells.

As it is illustrated in Figure 2-P, in CLL cell group classified as partially sensitive to $\mathrm{CM}, 50 \mu \mathrm{M}$ atorvastatin displayed the most antileukemic potential from among all tested atorvastatin doses, similarly as CM combination, while $\mathrm{CM}+\mathrm{A} 10$ combination induced $\sim 10 \%$ decrease in the cell viability in comparison to $\mathrm{CM}$. The effect caused by these drugs was additive.

In contrast, in CM-susceptible CLL cell group the CM combination operated more efficiently than atorvastatin used at all tested concentrations (compare Figure 2-S). Atorvastatin also indicated cytotoxic potential higher than that observed in CM-resistant CLL cells. Although combined action of atorvastatin and CM showed infra-additive effect on the leukemic PBMCs, the increase in antileukemic activity of examined agents was statistically significant $(p<0.01$ for $\mathrm{CM}$ and $\mathrm{CM}+\mathrm{A} 10$ pair of samples and $p<0.002$ for higher statin concentrations; Wilcoxon signed rank test). On average, adding $10 \mu \mathrm{M}$ atorvastatin to CM triggered only about $5 \%$ decrease in examined cell viability in comparison to conventional CM combination.

Meanwhile, as it is shown in Figure 3, the preincubation of CLL cell samples with atorvastatin, even at $1 \mu \mathrm{M}$, diminished their viability in comparison to the cells treated only with CM (without the previous preincubation).
3.3. DNA Content. DNA content assays were performed in cell samples from blood of 13 CLL patients. The average results of DNA content analysis in PBMCs exposed to the examined drugs are presented in Figure 1(c). Sub-G1 cell population of PBMCs corresponding to the population with apoptotic DNA fragmentation enlarged after 24 and $48 \mathrm{~h}$ incubation with all the tested agents in comparison to control (and the cells exposed to DMSO, solvent for atorvastatin). There was no difference between the DNA content in control cells and the vehicle control. The CM combination induced 4- and 3-fold increase in sub-G1 cell number in comparison to control PBMCs after 24 and $48 \mathrm{~h}$, respectively. Apoptosis confirmed by the presence of sub-G1 cells rises in statin-treated PBMCs in dose-dependent manner. The lowest concentration of atorvastatin triggered 2-fold raise of subdiploid PBMC population in comparison to control with DMSO. Atorvastatin used solely at the concentration of $50 \mu \mathrm{M}$ induced the changes in DNA content of the cells higher than those observed in PBMC samples incubated with $\mathrm{CM}(\sim 50 \%$ versus $43 \%)$. Importantly, the combined treatment of the model cells with $10 \mu \mathrm{M}$ atorvastatin and $\mathrm{CM}$ was more effective ( $15 \%$ and more) than CM alone. The adding of atorvastatin at higher concentrations than $10 \mu \mathrm{M}$ to $\mathrm{CM}$ combination increased antileukemic potential of the latter. In some cases, however, extreme DNA nucleolysis made impossible to reliably analyze the DNA content of the cells (these cases were excluded from analysis).

3.4. Caspase-3 Activation. The percentage of PBMCs expressing the active form of caspase- 3 was assessed cytometrically. The obtained results confirm proapoptotic potential of used concentration of atorvastatin, CM, as well as CM in combination with atorvastatin. In the model cells, apoptosis induction intensified proportionally to the dose of investigated agents, gaining over $45 \%$ increase in CM-treated cells in comparison to control and over $40 \%$ and $65 \%$ in PBMCs exposed to atorvastatin at concentrations of $25 \mu \mathrm{M}$ and $50 \mu \mathrm{M}$, respectively (exemplary patient number 13; see Figure 1(d)). The mean proapoptotic potential of CM was higher than that of $25 \mu \mathrm{M}$ atorvastatin but lower than that of statin at $50 \mu \mathrm{M}$. Low increase in apoptotic cell number in vehicle control in comparison to the cells without DMSO was noted. Importantly, the treatment of leukemic cell probes with atorvastatin and CM together was more efficient than these drugs used separately.

3.5. Immunoblotting Assay. To evaluate the proapoptotic potential of atorvastatin in drug-treated CLL cells, the expression levels of chosen apoptosis markers, that is, poly(ADPribose) polymerase-1 (PARP-1) and lamin B1, were examined. Both of these nuclear proteins are proteolytically cleaved by active caspases in the execution phase of apoptosis [28, 29]. The obtained results confirmed the cleavage of these apoptotic markers followed by the cell exposure to CM combination, as well as to atorvastatin alone or to its combination with CM. In 5 cases, $48 \mathrm{~h}$ exposure to CM did not induce the changes in the expression level of the full length proteins with a mass of $116 \mathrm{kDa}$ and $67 \mathrm{kDa}$, respectively. However, after 
$\mathrm{R}$

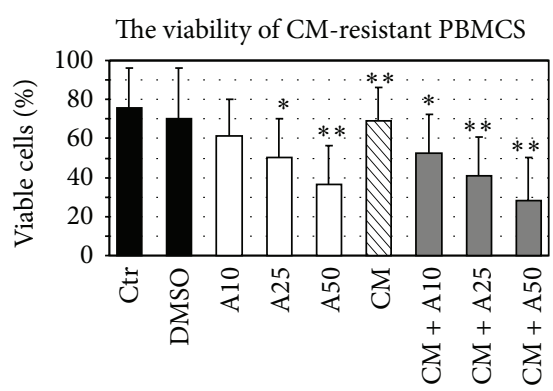

Drug exposure

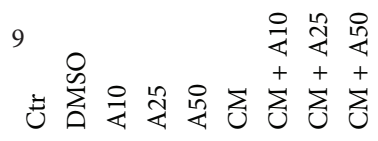

PARP-1
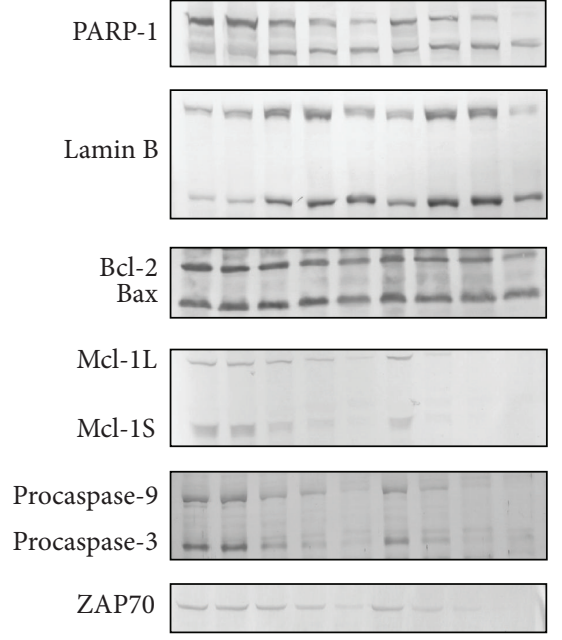

$49 \%$ of ZAP70 + CLL cells according to cytometric analysis

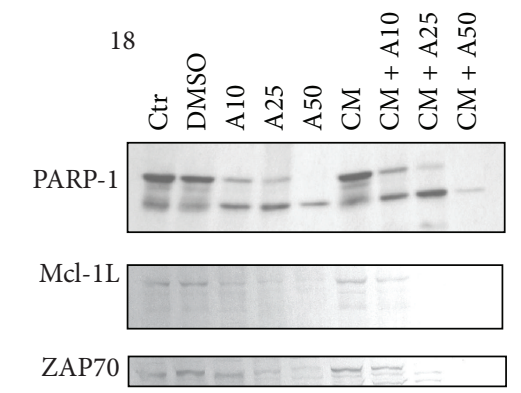

$37 \%$ of ZAP70 + CLL cells according to cytometric analysis
P

The viability of partially resistant PBMCS

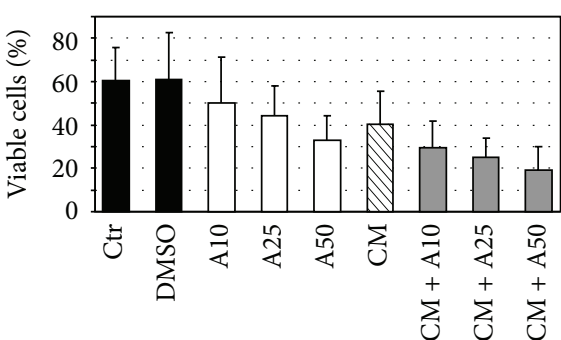

Drug exposure

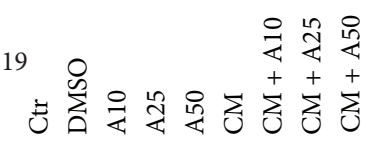

PARP-1

Mcl-1L

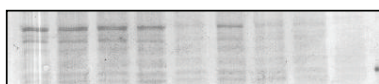

Procaspase-9
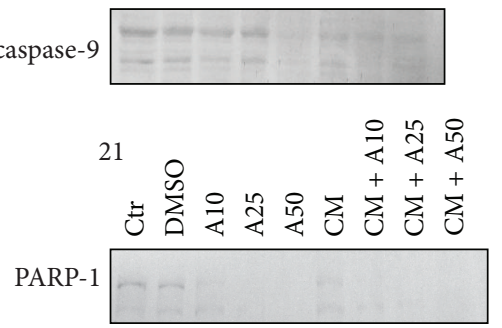

Mcl-1L
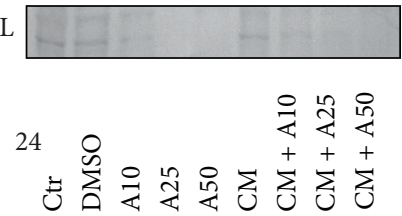

PARP-1

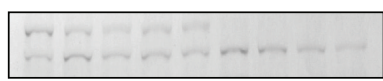

Mcl-1L

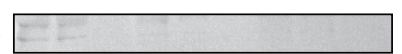

$S$

The viability of CM-susceptible PBMCS

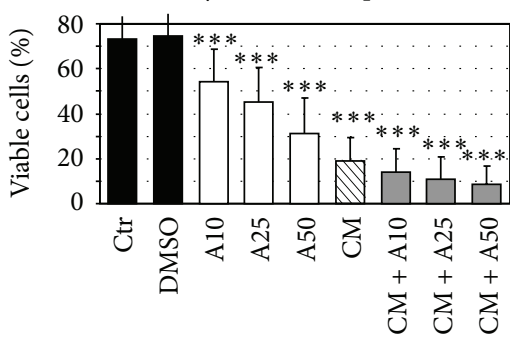

Drug exposure
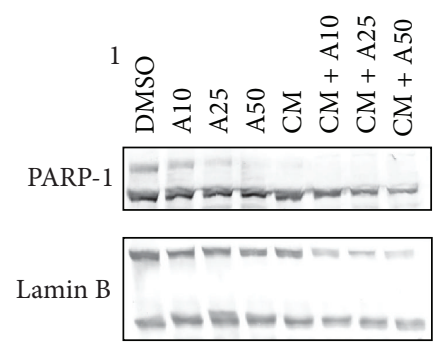

$\mathrm{Bax} \leadsto$

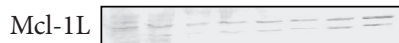

Mcl-1S

Procaspase-9 $\square=m-m$

Procaspase- $3 \square-\square-\square-\square$

ZAP70

$27 \%$ of ZAP70 + CLL cells according to cytometric analysis

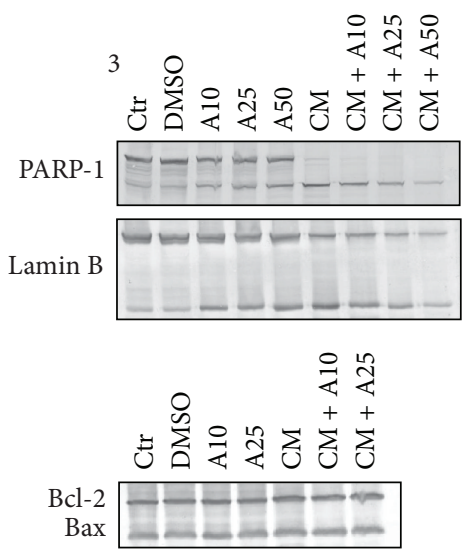

FIGURE 2: Antileukemic potential of atorvastatin (A), cladribine + mafosfamide combination (CM), or atorvastatin in combination with cladribine + mafosfamide $(\mathrm{CM}+\mathrm{A})$ in CM-resistant $(\mathrm{R})$, partially resistant $(\mathrm{P})$, and CM-susceptible (S) PBMC samples obtained from blood of exemplary CLL patients (numbers 1, 3, 9, 18, 19,21, and 24). The cytotoxic potential of the tested compounds was evaluated by Permeable/Dead Cell Apoptosis Kit and their proapoptotic activity was assessed by Western blot analysis of apoptosis-related protein expression after $48 \mathrm{~h}$ exposure. The results were statistically significant at ${ }^{*} p \leq 0.05,{ }^{* *} p \leq 0.02$, and ${ }^{* * *} p \leq 0.002$ (Wilcoxon signed rank test). 


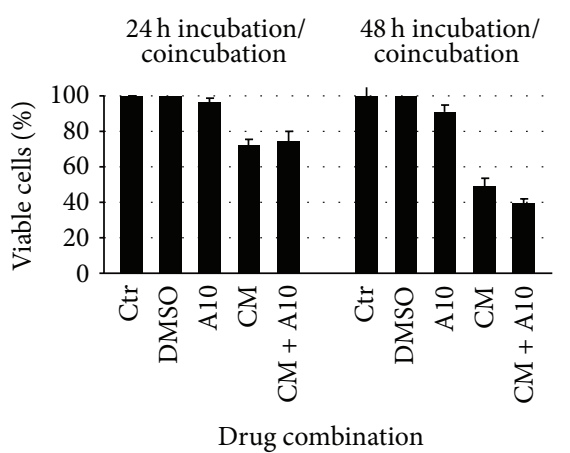

(a)

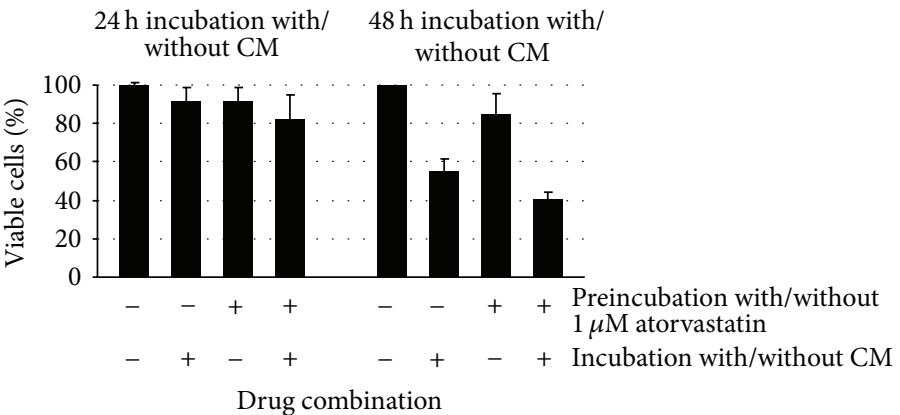

(b)

Figure 3: Antileukemic potential of atorvastatin (A) at $10 \mu \mathrm{M}$, cladribine + mafosfamide combination (CM), or atorvastatin in combination with cladribine + mafosfamide $(\mathrm{CM}+\mathrm{A})$ in comparison to the antileukemic potential of CM in PBMCs pretreated (or not) with atorvastatin at $1 \mu \mathrm{M}$.

the incubation of CLL cells with atorvastatin at rising concentration, the proteolysis of PARP-1 and lamin B1 was observed in 4 of them. Concomitantly, the elevated cleavage products of $85 \mathrm{kDa}$ and $44 \mathrm{kDa}$, respectively, were seen. Hence, a slight susceptibility of leukemic cells to cladribine and mafosfamide does not have to be related to their resistance to the statin.

The investigation of procaspase- 9 and procaspase- 3 expression by Western blot revealed that the used compounds influenced cellular level of the zymogens which was presumably caused by the activation of these enzymes (see Figure 2). The obtained data suggest an involvement of mitochondria in apoptosis course in CLL cells exposed to the tested agents. Similarly, Cafforio et al. [30] have previously indicated mitochondria as the organelles involved in statin-induced apoptosis. We postulate, however, that these organelles are not central for initiation of apoptosis in statintreated CLL cells. The mitochondrial pathway of apoptosis in statin-treated cells was not firmly confirmed by Bcl-2 (Bcell leukemia/lymphoma 2) family protein expression data. Although the dropping of Mcl-1 (myeloid cell leukemia 1; $\sim 40 \mathrm{kDa}$ ) cellular level was seen in most cases of CLL samples, as it is shown in Figure 2, this change was not accompanied by the spectacular diversities in the expression level of antiapoptotic-Bcl-2 and proapoptotic-Bax (Bcl-2 associated $\times$ protein) proteins. The increased Bax expression was observed in CM-sensitive CLL cell probes after their exposure to the conventional CM combination or its application with atorvastatin (see Figure 2-S). Additionally, a comparison of these protein expression levels revealed that the proteolysis of apoptosis-related proteins, PARP-1 and lamin B1, was observed together with the putative activation of caspase- 9 and caspase-3, and it sometimes proceded the Mcl-1 level decline (see Figure 2-S; patient number 1 and Figure 2-P; patient number 19). Therefore, it suggests that the alterations in Mcl-1 expression could be associated with its proteolysis during apoptosis, not the reason of apoptosis induction. Importantly, the Bcl-2 expression decline was only seen after the cell exposure to the highest drug concentrations.

Furthermore, the expression of ZAP70 kinase was estimated in several CLL cell samples incubated with atorvastatin alone, $\mathrm{CM}$, and $\mathrm{CM}$ with atorvastatin. A high intracellular expression of this enzyme is thought to be a negative prognostic factor for CLL [2]. Of note, Western blot assay indicated that in vitro exposure to atorvastatin resulted in ZAP70 kinase decrease in PBMCs from blood of ZAP70-positive patients (the positivity was confirmed by flow cytometry) that is in agreement with the results of Yavasoglu et al. [31]. The observed ZAP70 protein level decline is likely to be associated with executive phase of apoptosis, since analogous effect was also detected in CM-susceptible leukemic cells obtained from blood of exemplary patient number 1 exposed in vitro to CM. Moreover, no correlation between ZAP70 expression and the susceptibility of PBMC samples to the tested drug(s) was noticed.

The causal involvement of apoptosis disturbances and chromosomal aberrations and the evaluation of leukemic cell responses to drugs/experimental compounds have been demonstrated in leukemia cell lines [32,33], primary CLL cell samples [33-36], and animal models [37, 38]. Recently, reported data presented in vivo mouse models $[38,39]$ to explain how different components of the microenvironment contribute to this hematological neoplasm pathogenesis. An interesting approach involving the usage of CLL cells/nurselike cells coculture model for the investigation leukemia cellsmicroenvironment interactions after drug treatment was described [40]. The in vitro testing of CLL cells exposed to drug(s) was applied in Differential Staining Cytotoxicity test, DiSC [34], which recently was improved and simplies as TRAC (tumor response to antineoplastic compounds) [35, 41].

Summarizing, our results reveal that atorvastatin essentially increases the proapoptotic potential of drug combination, CM in CLL cells in vitro. In addition, even small doses of atorvastatin applied during the preincubation might intensify the cytotoxicity of CM against the leukemic cells in vitro. It seems, therefore, that atorvastatin usage by CLL patients during or before anticancer therapy is not a counterindication to cladribine and cyclophosphamide application. Conversely, it might intensify the efficacy of conventional chemotherapy. Supportive effect of atorvastatin and CM combination may be associated with their distinct modes of action. The conventional anticancer agents trigger cell death mainly by 
generating injuries within DNA and RNA molecules leading to apoptosis on mitochondrial pathway [42]. The metabolic changes provoked by statins in leukemic cells might induce cell death regardless of the changes in the $\mathrm{Bcl}-2$ family protein expression and caspase- 9 activation. It may be associated with endoplasmic reticulum (ER) stress-dependent apoptosis, which is a major mechanism involved in spontaneous apoptosis of CLL cells, or autophagy [43-45]. In addition to proapoptotic potential, atorvastatin might also affect the efflux of anticancer agents outside the cells, similarly as lovastatin which has been shown to inhibit the activity of (ATP) binding casette drug transporters in leukemic cells [46].

It has been previously suggested that statins should not be administered to the patients cured with immunotherapy [47]. The combined treatment of statins and monoclonal antibodies was unadvisable due to possible influence of these drugs on cellular localization and structure of leukemic cell antigens. Very recently published data suggest, however, that statins marginally affect rituximab-dependent ADCC (antibody dependent cellular cytotoxicity) [48]. Interestingly, it has been recently established that cholesterol molecules mask tumor-associated membrane glycosphingolipids enabling tumor escape from immune system recognition. Hence, statins could facilitate immunosurveillance by the reduction of cholesterol level in the membranes of some types of cancer $[49,50]$. In light of these data it seems possible that the benefits of statin cotreatment might be higher than their disadvantages also for the patients treated with immunotherapy. Some of lately published results indicating improved response rate and survival among the patients with relapsed or refractory CLL who received statins and/or aspirin together with RCF have supported above notion [51]. Similarly, Lee et al. have [52] revealed that statins are able to potentiate the antiangiogenic effects of bevacizumab in colorectal cancer cells. On the other hand, there are a lot of controversies associated with statin usage $[50,53]$. High dose of atorvastatin used during anticancer therapy might result in drug induced liver injury (DILI) in susceptible patients [54]. Another possibility is enhanced risk of diabetes development, especially among elder patients. The diabetogenic potential of statins occurring after about 4-year treatment with statins was reported [55].

\section{Conclusions}

The obtained results indicate that in vitro atorvastatin alone is able to induce apoptosis in CM-sensitive and CM-resistant chronic lymphocytic leukemia cells. Moreover, coincubation or preincubation with atorvastatin sensitizes CLL cells to CM-induced apoptosis and should be considered as therapeutic option for CLL patients. It seems that the patients who are CM-resistant and/or these ones with poor prognostic markers for the treatment with conventional chemotherapy might have bigger benefits from atorvastatin introduction.

\section{Conflict of Interests}

The authors declare that there is no conflict of interests regarding the publication of this paper.

\section{Acknowledgments}

This work was supported by Grant no. 1407 from the University of Łódź. The authors would like to thank the colleagues from Laboratory of Cytometry, University of Łódź, for cytometric measurements of cell viability/apoptosis rate and caspase- 3 activation.

\section{References}

[1] G. Gaidano, R. Foà, and R. Dalla-Favera, "Molecular pathogenesis of chronic lymphocytic leukemia," The Journal of Clinical Investigation, vol. 122, no. 10, pp. 3432-3438, 2012.

[2] P. Smolewski, M. Witkowska, and A. Korycka-Wołowiec, "New insights into biology, prognostic factors, and current therapeutic strategies in chronic lymphocytic leukemia," ISRN Oncology, vol. 2013, Article ID 740615, 7 pages, 2013.

[3] M. Wu, A. Akinleye, and X. Zhu, "Novel agents for chronic lymphocytic leukemia," Journal of Hematology and Oncology, vol. 6, no. 1, article 36, 2013.

[4] A. Cuneo, F. Cavazzini, M. Ciccone et al., "Modern treatment in chronic lymphocytic leukemia: impact on survival and efficacy in high-risk subgroups," Cancer Medicine, vol. 3, no. 3, pp. 555564, 2014.

[5] L. Amrein, M. Shawi, J. Grenier, R. Aloyz, and L. Panasci, "The phosphatidylinositol-3 kinase i inhibitor BKM120 induces cell death in B-chronic lymphocytic leukemia cells in vitro," International Journal of Cancer, vol. 133, no. 1, pp. 247-252, 2013.

[6] J. C. Gea-Banacloche, "Rituximab-associated infections," Seminars in Hematology, vol. 47, no. 2, pp. 187-198, 2010.

[7] A. R. Tonelli, R. Lottenberg, R. W. Allan, and P. S. Sriram, "Rituximab-induced hypersensitivity pneumonitis," Respiration, vol. 78, no. 2, pp. 225-229, 2009.

[8] M. L. Hartman and Z. M. Kilianska, "Lipoprotein lipase: a new prognostic factor in chronic lymphocytic leukaemia," Contemporary Oncology, vol. 16, no. 6, pp. 474-479, 2012.

[9] D. E. Spaner, E. Lee, Y. Shi et al., "PPAR-alpha is a therapeutic target for chronic lymphocytic leukemia," Leukemia, vol. 27, no. 5, pp. 1090-1099, 2013.

[10] M. F. Mulas, C. Abete, D. Pulisci et al., "Cholesterol esters as growth regulators of lymphocytic leukaemia cells," Cell Proliferation, vol. 44, no. 4, pp. 360-371, 2011.

[11] T. P. Ahern, T. L. Lash, P. Damkier, P. M. Christiansen, and D. P. Cronin-Fenton, "Statins and breast cancer prognosis: evidence and opportunities," The Lancet Oncology, vol. 15, no. 10, pp. e461-e468, 2014

[12] P. Jiang, R. Mukthavaram, Y. Chao et al., "In vitro and in vivo anticancer effects of mevalonate pathway modulation on human cancer cells," British Journal of Cancer, vol. 111, no. 8, pp. 1562-1571, 2014.

[13] A. Sławińska-Brych, B. Zdzisińska, and M. Kandefer-Szerszeń, "Fluvastatin inhibits growth and alters the malignant phenotype of the C6 glioma cell line," Pharmacological Reports, vol. 66, no. 1, pp. 121-129, 2014.

[14] W. A. Maltese and J. R. Aprille, "Relation of mevalonate synthesis to mitochondrial ubiquinone content and respiratory function in cultured neuroblastoma cells," The Journal of Biological Chemistry, vol. 260, no. 21, pp. 11524-11529, 1985.

[15] I.-M. Astrand, E. Fries, T. Chojnacki, and G. Dallner, "Inhibition of dolichyl phosphate biosynthesis by compactin in cultured rat 
hepatocytes," European Journal of Biochemistry, vol. 155, no. 2, pp. 447-452, 1986.

[16] A. W. Alberts, "Lovastatin and simvastatin-inhibitors of HMG CoA reductase and cholesterol biosynthesis," Cardiology, vol. 77, no. 4, pp. 14-21, 1990.

[17] N. Vallianou, A. Kostantinou, M. Kougias, and C. Kazazis, "Statins and Cancer," Anti-Cancer Agents in Medicinal Chemistry, vol. 14, no. 5, pp. 706-712, 2014.

[18] J. H. Jackson, C. G. Cochrane, J. R. Bourne, P. A. Solski, J. E. Buss, and C. J. Der, "Farnesol modification of Kirsten-ras exon 4B protein is essential for transformation," Proceedings of the National Academy of Sciences of the United States of America, vol. 87, no. 8, pp. 3042-3046, 1990.

[19] A. A. Al-Haidari, I. Syk, and H. Thorlacius, "HMG-CoA reductase regulates CCL17-induced colon cancer cell migration via geranylgeranylation and RhoA activation," Biochemical and Biophysical Research Communications, vol. 446, no. 1, pp. 68-72, 2014.

[20] S. Ishikawa, H. Hayashi, K. Kinoshita et al., "Statins inhibit tumor progression via an enhancer of zeste homolog 2mediated epigenetic alteration in colorectal cancer," International Journal of Cancer, vol. 135, no. 11, pp. 2528-2536, 2014.

[21] M. Podhorecka, D. Halicka, P. Klimek, M. Kowal, S. Chocholska, and A. Dmoszynska, "Simvastatin and purine analogs have a synergic effect on apoptosis of chronic lymphocytic leukemia cells," Annals of Hematology, vol. 89, no. 11, pp. 1115-1124, 2010.

[22] J. D. Zołnierczyk, A. Borowiak, P. Hikisz et al., "Promising antileukemic activity of atorvastatin," Oncology Reports, vol. 29, no. 5, pp. 2065-2071, 2013.

[23] B. D. Cheson, J. M. Bennett, M. Grever et al., "National Cancer Institute-sponsored Working Group guidelines for chronic lymphocytic leukemia: revised guidelines for diagnosis and treatment," Blood, vol. 87, no. 12, pp. 4990-4997, 1996.

[24] A. Kobylińska, J. Bednarek, J. Z. Blonski et al., "In vitro sensitivity of B-cell chronic lymphocytic leukemia to cladribine and its combinations with mafosfamide and/or mitoxantrone," Oncology Reports, vol. 16, no. 6, pp. 1389-1395, 2006.

[25] O. H. Lowry, N. J. Rosebrough, A. L. Farr, and R. J. Randall, "Protein measurement with the Folin phenol reagent," The Journal of Biological Chemistry, vol. 193, no. 1, pp. 265-275, 1951.

[26] U. K. Laemmli, "Cleavage of structural proteins during the assembly of the head of bacteriophage T4," Nature, vol. 227, no. 5259, pp. 680-685, 1970.

[27] H. Towbin, T. Staehelin, and J. Gordon, "Electrophoretic transfer of proteins from polyacrylamide gels to nitrocellulose sheets: Procedure and some applications," Proceedings of the National Academy of Sciences of the United States of America, vol. 76, no. 9, pp. 4350-4354, 1979.

[28] D. J. McConkey, “Calcium-dependent, interleukin 1-converting enzyme inhibitor-insensitive degradation of lamin B1 and DNA fragmentation in isolated thymocyte nuclei," The Journal of Biological Chemistry, vol. 271, no. 37, pp. 22398-22406, 1996.

[29] P. Garnier, W. Ying, and R. A. Swanson, "Ischemic preconditioning by caspase cleavage of poly(ADP-ribose) polymerase-1," Journal of Neuroscience, vol. 23, no. 22, pp. 7967-7973, 2003.

[30] P. Cafforio, F. Dammacco, A. Gernone, and F. Silvestris, "Statins activate the mitochondrial pathway of apoptosis in human lymphoblasts and myeloma cells," Carcinogenesis, vol. 26, no. 5, pp. 883-891, 2005.

[31] I. Yavasoglu, G. Sargin, G. Kadikoylu, A. Karul, and Z. Bolaman, "The activity of atorvastatin and rosiglitazone on CD38, ZAP70 and apoptosis in lymphocytes of B-cell chronic lymphocytic leukemia in vitro," Medical Oncology, vol. 30, no. 3, article 603, 2013.

[32] S. Al-harbi, B. T. Hill, S. Mazumder et al., "An antiapoptotic BCL-2 family expression index predicts the response of chronic lymphocytic leukemia to ABT-737," Blood, vol. 118, no. 13, pp. 3579-3590, 2011.

[33] A. Furlan, F. Villanova, F. Pietrogrande, M. Celadin, M. Sanzari, and F. Vianello, "Low-dose fludarabine increases rituximab cytotoxicity in B-CLL cells by triggering caspases activation in vitro," Leukemia \& Lymphoma, vol. 51, no. 1, pp. 107-113, 2010.

[34] A. G. Bosanquet and P. B. Bell, "Enhanced ex vivo drug sensitivity testing of chronic lymphocytic leukaemia using refined disc assay methodology," Leukemia Research, vol. 20, no. 2, pp. 143-153, 1996.

[35] A. G. Bosanquet, S. M. Richards, R. Wade et al., "Drug crossresistance and therapy-induced resistance in chronic lymphocytic leukaemia by an enhanced method of individualised tumour response testing," British Journal of Haematology, vol. 146, no. 4, pp. 384-395, 2009.

[36] J. D. Żołnierczyk, A. Borowiak, J. Z. Blonski et al., "In vivo and ex vivo responses of CLL cells to purine analogs combined with alkylating agent," Pharmacological Reports, vol. 65, no. 2, pp. 460-475, 2013.

[37] X.-J. Yan, E. Albesiano, N. Zanesi et al., "B cell receptors in TCL1 transgenic mice resemble those of aggressive, treatmentresistant human chronic lymphocytic leukemia," Proceedings of the National Academy of Sciences of the United States of America, vol. 103, no. 31, pp. 11713-11718, 2006.

[38] U. Klein and R. Dalla-Favera, "New insights into the pathogenesis of chronic lymphocytic leukemia," Seminars in Cancer Biology, vol. 20, no. 6, pp. 377-383, 2010.

[39] D. Bagnara, M. S. Kaufman, C. Calissano et al., "A novel adoptive transfer model of chronic lymphocytic leukemia suggests a key role for T lymphocytes in the disease," Blood, vol. 117, no. 20, pp. 5463-5472, 2011.

[40] A. A. Filip, B. Ciseł, and E. Wąsik-Szczepanek, "Guilty bystanders: nurse-like cells as a model of microenvironmental support for leukemic lymphocytes," Clinical and Experimental Medicine, vol. 15, no. 1, pp. 73-83, 2015.

[41] E. Matutes, A. G. Bosanquet, R. Wade, S. M. Richards, M. Else, and D. Catovsky, "The use of individualized tumor response testing in treatment selection: second randomization results from the LRF CLL4 trial and the predictive value of the test at trial entry," Leukemia, vol. 27, no. 2, pp. 507-510, 2013.

[42] T. Robak and P. Robak, "Purine nucleoside analogs in the treatment of rarer chronic lymphoid leukemias," Current Pharmaceutical Design, vol. 18, no. 23, pp. 3373-3388, 2012.

[43] E. Rosati, R. Sabatini, G. Rampino et al., "Novel targets for endoplasmic reticulum stress-induced apoptosis in B-CLL," Blood, vol. 116, no. 15, pp. 2713-2723, 2010.

[44] X. Peng, W. Li, L. Yuan, R. G. Mehta, L. Kopelovich, and D. L. McCormick, "Inhibition of proliferation and induction of autophagy by atorvastatin in PC3 prostate cancer cells correlate with downregulation of $\mathrm{Bcl} 2$ and upregulation of miR-182 and p21," PLoS ONE, vol. 8, no. 8, Article ID e70442, 2013.

[45] S. Ghavami, P. Sharma, B. Yeganeh et al., "Airway mesenchymal cell death by mevalonate cascade inhibition: integration of autophagy, unfolded protein response and apoptosis focusing on Bcl2 family proteins," Biochimica et Biophysica Acta, vol. 1843, no. 7, pp. 1259-1271, 2014. 
[46] E. Głodkowska-Mrowka, P. Mrowka, G. W. Basak et al., "Statins inhibit $A B C B 1$ and $A B C G 2$ drug transporter activity in chronic myeloid leukemia cells and potentiate antileukemic effects of imatinib," Experimental Hematology, vol. 42, no. 6, pp. 439-447, 2014.

[47] M. Winiarska, J. Bil, E. Wilczek et al., "Statins impair antitumor effects of Rituximab by inducing conformational changes of CD20," PLoS Medicine, vol. 5, no. 3, article e64, 2008.

[48] A. Poggi, S. Boero, A. Musso, and M. R. Zocchi, "Selective role of mevalonate pathway in regulating perforin but not FasL and TNFalpha release in human natural killer cells," PLOS ONE, vol. 8, no. 5, Article ID e62932, 2013.

[49] A. Novak, B. Binnington, B. Ngan, K. Chadwick, N. Fleshner, and C. A. Lingwood, "Cholesterol masks membrane glycosphingolipid tumor-associated antigens to reduce their immunodetection in human cancer biopsies," Glycobiology, vol. 23, no. 11, pp. 1230-1239, 2013.

[50] S. Pisanti, P. Picardi, E. Ciaglia, A. D’Alessandro, and M. Bifulco, "Novel prospects of statins as therapeutic agents in cancer," Pharmacological Research, vol. 88, pp. 84-98, 2014.

[51] Y. K. Chae, L. Trinh, P. Jain et al., "Statin and aspirin use is associated with improved outcome of FCR therapy in relapsed/refractory chronic lymphocytic leukemia.," Blood, vol. 123, no. 9, pp. 1424-1426, 2014.

[52] S. J. Lee, I. Lee, J. Lee, C. Park, and W. K. Kang, "Statins potentiate the anti-angiogenic effects of bevacizumab in human colorectal cancer," The British Journal of Cancer, vol. 111, no. 3, pp. 497-505, 2014.

[53] S. Bonovas, "Statins: do they have a potential role in cancer prevention and modifying cancer-related outcomes?" Drugs, vol. 74, no. 16, pp. 1841-1848, 2014.

[54] M. F. Carrascosa, J. R. Salcines-Caviedes, M. I. Lucena, and R. J. Andrade, "Acute liver failure following atorvastatin dose escalation: is there a threshold dose for idiosyncratic hepatotoxicity?" Journal of Hepatology, vol. 62, no. 3, pp. 751-752, 2015.

[55] U. K. Sampson, M. F. Linton, and S. Fazio, "Are statins diabetogenic?” Current Opinion in Cardiology, vol. 26, no. 4, pp. 342347, 2011. 

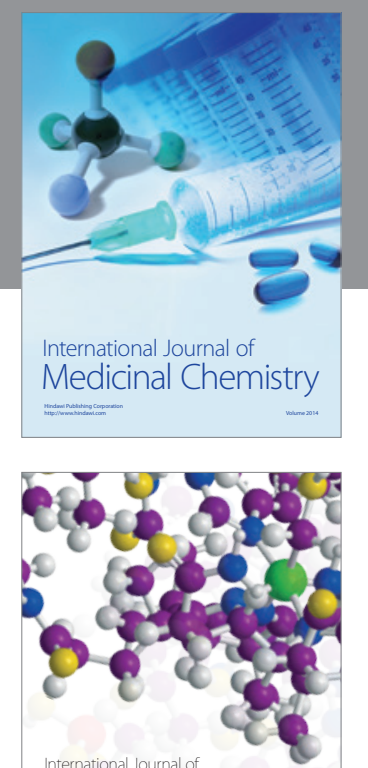

\section{Carbohydrate} Chemistry

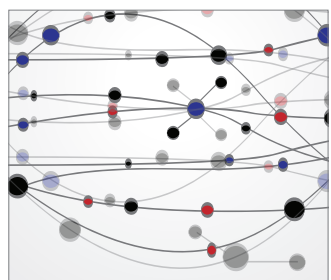

The Scientific World Journal
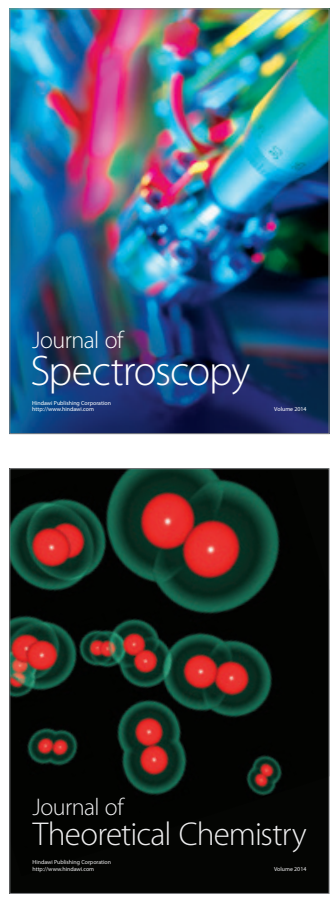
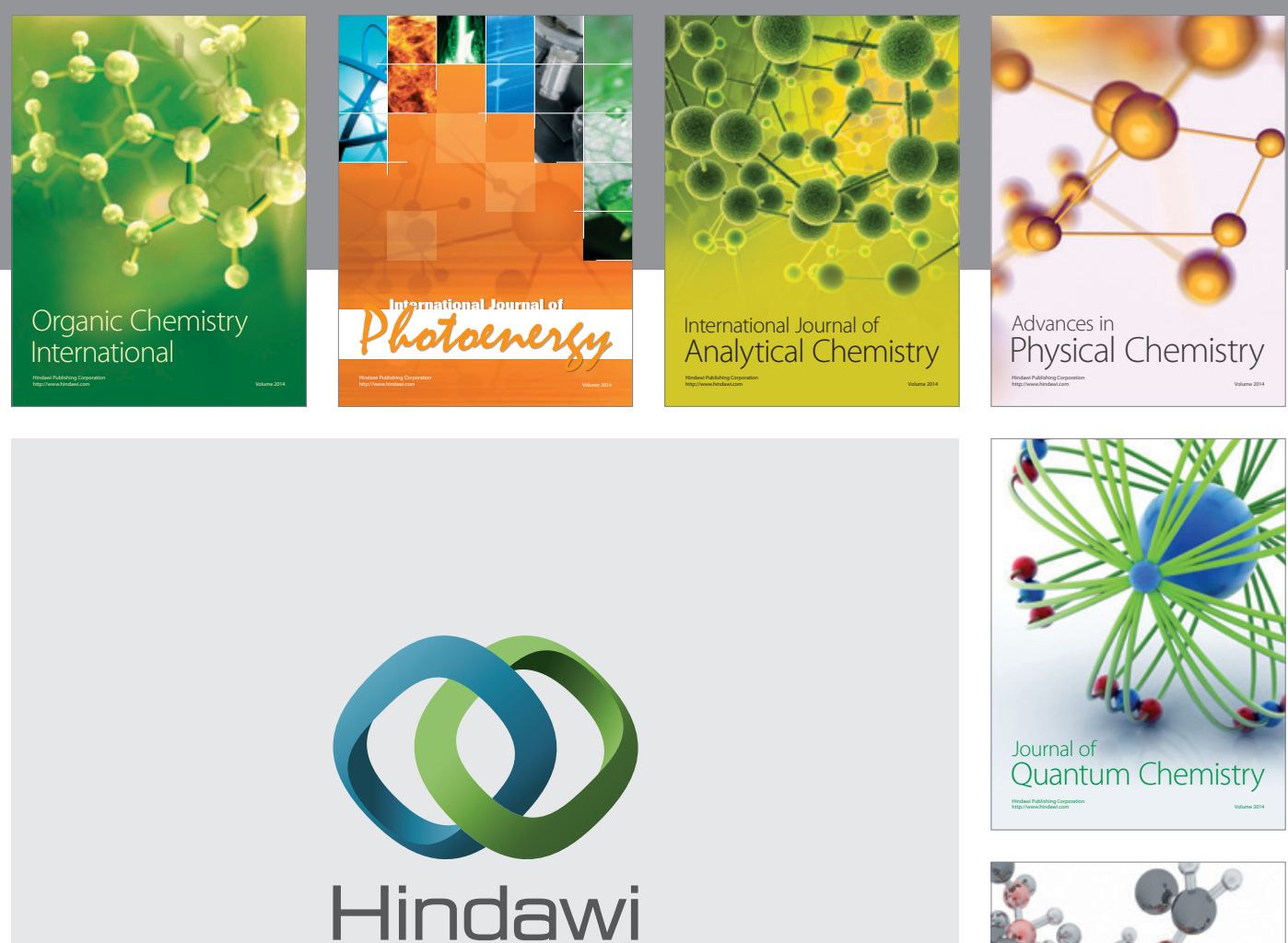

Submit your manuscripts at

http://www.hindawi.com

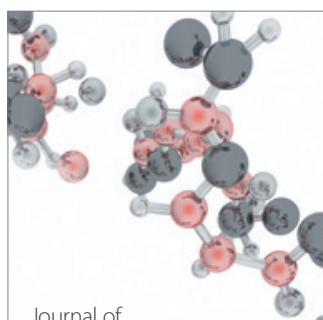

Analytical Methods

in Chemistry

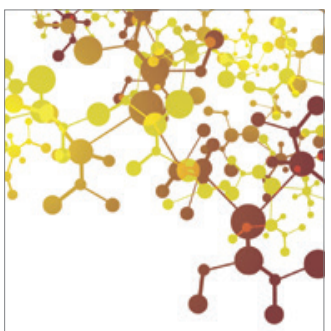

Journal of

Applied Chemistry

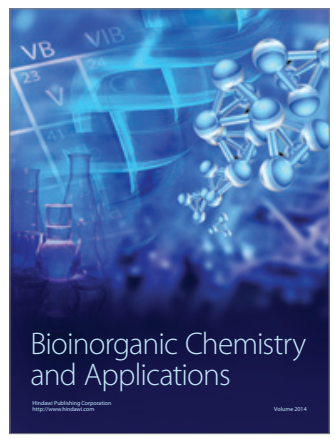

Inorganic Chemistry
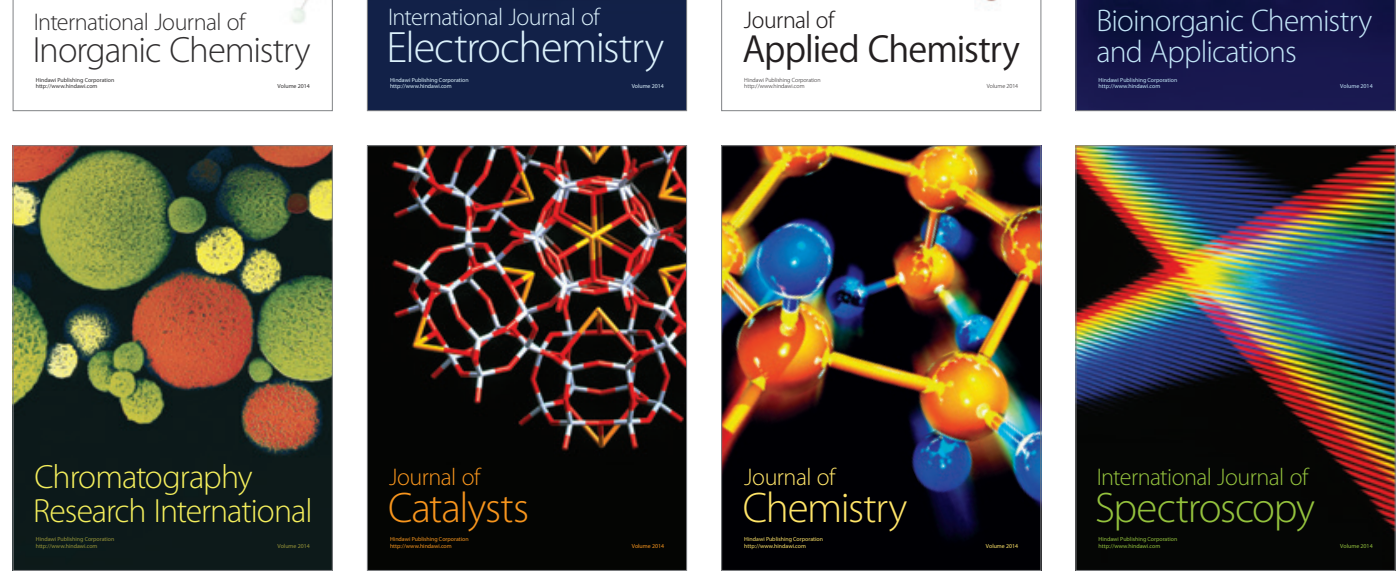